\title{
The Problem of Accounting for the Costs Incurred after the Initial Recognition of an Intangible Asset
}

\author{
Vetoshkina E.Yu. \\ Kazan Federal University, Institute of Management, Economics and Finance, Kazan, 420008, Russia \\ Email: pulya_1978@mail.ru
}

Tukhvatullin R.Sh.

Kazan Federal University, Institute of Management, Economics and Finance, Kazan, 420008, Russia

\section{Doi:10.5901/mjss.2014.v5n24p52}

\section{Abstract}

The article comprises a set of theoretical and methodological statements and practical suggestions about the specific ways of disclosing information on the costs of completion of intangible assets. IAS 38 Intangible assets contain the extensive list of norms regulating initial recognition and approaches to the assets evaluation at initial and further recognition and determines the rules of intangible assets. However, the problem of accounting for the additional costs incurred after the initial recognition of intangible assets is not illustrated enough.

Keywords: intangible assets, maintenance costs, the costs for software revision, initial recognition

\section{Introduction}

It is becoming increasingly clear in today's economic development that not only tangible assets can bring economic benefit to companies. A couple of decades ago, it was hard to imagine that the assets without a real tangible embodiment would be reflected in the balance sheet along with material assets. The existence of rights that protect intellectual property, contractual and other rights to operate physical assets and infrastructure, purchase and sale of broadcasting rights in the telecommunications sector, the implementation of spending on research and development - all these features characterize the activities of modern companies.

Figure 1 represents the differences in fixed versus intangible assets for various businesses according to their annual reporting. In this regard, the most interesting fact is that the largest share of the total assets are intangible assets in the service sector while in the service industry and the oil industry the share of intangible assets is negligible.

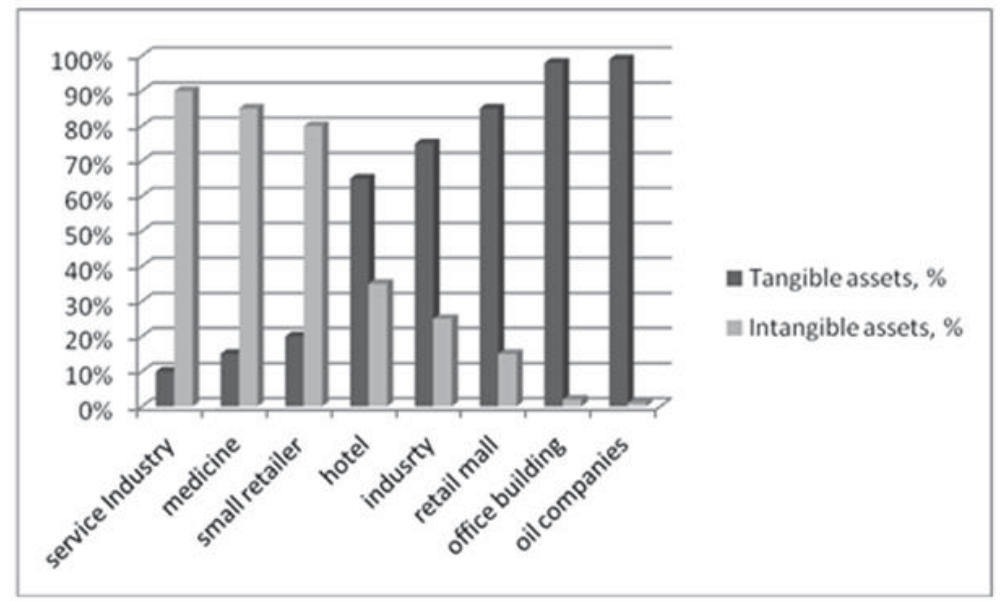

Fig. 1. Differences in Fixed versus Intangible Assets for Various Businesses 
The IASB has developed common rules for intangible assets that are not regarded separately in any other standard, IAS 38 Intangible assets. Accounting issues of specific intangible assets, including the cost of developing and maintaining websites, are presented in SIC -32. But management choice to record intangible assets is associated with the strength of the technology affecting the firm's operations the length of the technology cycle time and property-rights-related factors that affect the firm's ability to appropriate the investment benefits (Anne Wyatt, 2005).

This research deals with the accounting of expenses for subsequent costs after the initial recognition of intangible assets in the form of improvements in its qualitative characteristics while operation.

Computer programs are considered to be the results of intellectual activity (intellectual property), which should be provided with the legal protection. In the process of revision and adaptation of a computer program, carried out by a special company under contract with the owner of the intangible asset, a variety of additional software modules (subroutines), altering the characteristics of the main program, may appear. Exclusive rights for such software modules (programs) belong to the contracting authority, unless other is stipulated by the contract (Erik Brynjolfsson, et al., 2002). The owning company can also make changes in the software on its own.

IAS 38 Intangible assets contains extensive list of norms regulating initial recognition and approaches to the assets evaluation at initial and further recognition, and determines the rules of intangible assets. Questions of identification and evaluation of intangible assets are presented in the most interesting works of the following scholars: Anne Marie Knott (2003), Lie Dharma (2009), Kulikova L.I. (2009), Richard N. Cooper (2010).

However, the problem of accounting for the additional costs incurred after the initial recognition of intangible assets is not illustrated enough.

\section{Theory}

Due to this, we should point out that the recognition of intangible assets in IAS is based on the general principle applying to both the initial acquisition, and the subsequent costs, however, the latter requires more stringent conditions for recognition as an expense in the cost for revision of an existing intangible asset (Kulikova L.I. and Goshunova A.V., 2014). Thus, the standard defines the possibility of increasing the cost of an intangible asset in the case of the revision of the item if the cost of these works is directly linked to the improvement of the characteristics of a particular intangible asset. However, as the following paragraph 20 IAS 38 states, the nature of intangible assets is such that in many cases, improvement or partial replacement of such assets doesn't take place (Naomi A. Gardberg and Charles J. Fombrun, 2006). According to this, the most subsequent expenditures forming the expected future economic benefits and consisting in an existing intangible asset as a rule are not able to meet the definition of an intangible asset and the recognition criteria set out in the standard.

In addition, paragraph 63 of IAS 38 specifies that subsequent expenditure on intangible assets such as brands, mastheads, publishing titles, customer lists and articles of similar content is always recognized in profit or loss as they appear. This is due to the fact that these costs are connected with the expansion costs in general (Valeria Gattai, 2010). Thus, the rules of IFRS imply that almost all the additional costs to improve the quality characteristics of any intangible asset can not be capitalized as part of the previously received intangible asset. Indeed, this increase is possible only in extreme cases. Standard IAS 38 Intangible assets does not specify what these «extreme cases» may be.

However, we think that sometimes economic inexpediency of excluding additional costs in the value of an existing intangible asset or account of these costs in the cost of the current period takes place not at the same time but evenly.

\section{Results}

Here we are speculating on the cost accounting to finalize software previously adopted by the company as an intangible asset. We should point out that the cost of the subsequent revision of software, previously recognized as an intangible asset, can reach the quantities significant enough, especially if we talk about ERP systems such as SAP, Oracle, and etc. In the context of this research, we do not consider non-essential costs of maintaining the software, as they are recognized in profit or loss of the current period. Thus, telling about the cost of software maintenance costs we mean the costs for periodical update of the software (eg., accounting software), changing of releases, some insignificant improvements, and etc.

At the same time, costs for revision are the ones for making significant changes in the existing software, improving and modernizing the qualitative characteristics. For example, such costs may be connected with the work on the superstructure Module «Performance management» in a software company in the organization of financial accounting that will improve the characteristics of the software product (speed, reliability, convenience of the user interface, etc.). In 
this regard, it is important to mention that the company may not be able to identify these changes as a separate asset, as the plug-ins created in the process of refining and adapting the software may not be designed to perform independent functions. Their main function should be to provide the output improvement, and furthermore, the modules can not function independently of the main software.

However, under certain conditions when implementing modules (add-ons) to the existing software, the company may capitalize the expenses for their creation as a separate intangible asset. Consequently, if the software is recognized as an intangible asset and is used by both exposed refinement, the approach to the recognition of costs of completion, in our opinion, should be formed on the basis of the following scenarios:

Table 1: Approaches to the costs recognition

\begin{tabular}{|l|l|}
\hline Scenario & Content \\
\hline $\begin{array}{l}1 \text { the most commonly used in } \\
\text { practice }\end{array}$ & $\begin{array}{l}\text { the costs for software revision are unimportant, and subsequent costs provide the } \\
\text { expected economic benefits, but will not meet the general criteria for recognition as an } \\
\text { intangible asset }\end{array}$ \\
\hline 2 less applicable in practice & $\begin{array}{l}\text { the costs for software revision are important, and subsequent costs provide the } \\
\text { expected economic benefits, but will not meet the general criteria for recognition as an } \\
\text { intangible asset }\end{array}$ \\
\hline 3 not applicable & $\begin{array}{l}\text { the costs for software revision are important, and subsequent costs provide the } \\
\text { expected economic benefits and will meet the general criteria for recognition and } \\
\text { identification as an intangible asset }\end{array}$ \\
\hline
\end{tabular}

In the first case, we regard the costs for software revision as an expenses in the current period due to their immateriality, and as a consequence, it becomes an inappropriate capitalization.

In the second case, the costs for software revision are important, and therefore, we think that it is economically viable to capitalize the costs of software completion in individual «Other non-current non-financial assets» with further transferring its actual (original) cost on a uniform basis on production costs, works and services. For example, the useful life may be set depending on the duration of extracting economic benefits from the use of the modified software. This approach stems from the fact that the cost for revision is a substantial amount, and the income from the use of this asset is received in several reporting periods. But in this case one nuance appears, and it makes the possibility of such capitalization of software revision doubtful. The fact is that, as we have already mentioned, the company may not be able to identify the changes as an independent asset and to separate them from the previously recognized. Thus, the absence of the object's properties, such as being the source of alienable economic benefits, makes the possibility of its identification as a separate asset doubtful.

In the third and the most rare case, the cost of software revision should be capitalized in the cost of an intangible asset initially recognized on the following conditions:

- $\quad$ the cost of revision can be directly linked with the improvement of the characteristics of a particular intangible asset;

- $\quad$ as a result of the improvements the company will receive additional economic benefits in future;

- the company has a real opportunity to get a reliable evaluation of the costs incurred on completion of the intangible asset.

\section{Conclusions}

Such variety of specific ways of disclosing information on the costs of completion of intangible assets suggests that it is expedient to regulate their order autonomously, ie separately from the other categories of objects. However, we know, that the considered category of assets is not heterogeneous (Vetoshkina, 2009).

Thus, we see that the accounting model after the initial recognition of an object as an intangible asset, costs, assuming their capitalization as a part of the cost of an intangible asset (and, therefore, their correlation with the benefits received) should be defined as a separate element of the company's accounting policies in relation to specific types of intangible assets, such as software. 


\section{References}

Anne Marie Knott, David J. Bryce, Hart E. Posen On the Strategic Accumulation of Intangible Assets Organization Science, Vol. 14, 2 (Mar. - Apr., 2003), pp. 192-207.

Anne Wyatt Accounting Recognition of Intangible Assets: Theory and Evidence on Economic Determinants The Accounting Review, Vol. 80, 3 (Jul., 2005), pp. 967-1003.

Erik Brynjolfsson, Lorin M. Hitt, Shinkyu Yang Intangible Assets: Computers and Organizational Capital Brookings Papers on Economic Activity, Vol. 2002, 1 (2002), pp. 137-181.

Kulikova L.I., Goshunova A.V. Efficiency measurement of professional football clubs: a non-parametric approach. Life Science Journal. 2014; 11 (11s): 117-122.

Kulikova L.I. Estimation of Intangible Assets (according to IAS 38) International accounting, 2009, Vol. 7 (Jul., 2009) http://kpfu.ru/lidiya.kulikova

Lie Dharma Putra Accounting For Intangible Assets [IAS 38] With Case Examples http://accounting-financial-tax.com/2009/03/ accounting-for-intangible-assets-ias-38-with-case-examples/

Naomi A. Gardberg, Charles J. Fombrun Corporate Citizenship: Creating Intangible Assets across Institutional Environments The Academy of Management Review, Vol. 31, No. 2 (Apr., 2006), pp. 329-346.

Richard N. Cooper Review: From Poverty to Prosperity: Intangible Assets, Hidden Liabilities, and the Lasting Triumph Over Scarcity by Arnold King, Nick Schulz. Foreign Affairs, Vol. 89, 3 (May/June 2010), p. 136.

Valeria Gattai Firm's intangible assets and multinational activity: Full versus shared ownership The Journal of International Trade \& Economic Development, Volume 19, Issue 4, December 2010, pages 553-589.

Vetoshkina E. Yu. Topical Issues of Intangible Assets. International accounting, 2009, Vol. 2 (Feb., 2009) http://kpfu.ru/main? p_id=30624.

Fakhrutdinova, E., Kolesnikova, J., Yurieva, O., Kamasheva, A. The commercialization of intangible assets in the information society/l World Applied Sciences Journal. Volume 27, Issue 13, 2013, Pages 82-86.

Hajrullina A.D., Romadanova O.A. Technique of measurement of value of the human capital as intangible asset of corporation. Life Science Journal 2014; 11(6s): $518-521$.

Su, W.H., Wells, P. (2014). The association of identifiable intangible assets acquired and recognised in business acquisitions with postacquisition firm performance. Accounting and Finance, Article in Press

Feijóo, C., Gómez-Barroso, J.L.,Voigt, P. (2014). Exploring the economic value of personal information from firms' financial statements. International Journal of Information Management, 34 (2), pp. 248-256

Golec, J., Gupta, N.J. (2014). Do investments in intangible customer assets affect firm value? Quarterly Review of Economics and Finance, Article in Press. 